DE DE GRUYTER OPEN
Research Article

(C) 2018 Deinibiteim Monimah Harry and Winston Madume. This is an open access article licensed under the Creative Commons Attribution-NonCommercial-NoDerivs License (http://creativecommons.org/licenses/by-nc-nd/3.0/).

\title{
State Intervention/Bailout and Economic Stabilisation in Nigeria: Some Lessons from the United States
}

\author{
Deinibiteim Monimah Harry, Ph.D. \\ Winston Madume
}

Department of Public Administration Port Harcourt Polytechnic, Rumuola, Port Harcourt, Nigeria

Doi: $10.2478 / \mathrm{mjss}-2018-0049$

\begin{abstract}
The study examined the nature of state intervention during economic and/or financial crisis, focusing on Nigeria and US. These two nations have embarked on various kinds of bailouts to stabilize their economies and move their nations on the path of economic recovery and growth. However, the bailout effort is more successful in the US than Nigeria. This is largely due to the approach adopted in these countries. Thus, the main objective of this paper is to ascertain the extent to which government invention has helped stabilize the Nigerian economy, when compared with the experience of the United States. The study revealed that in the US every state intervention/ bailout is approved by congress through legislation, therefore well-guided in its administration or execution, with specific time lines. On the other hand, in Nigeria bailouts are by "executive fiat", as a result they suffer from poor execution. Hence, the paper concluded that state intervention/bailout in Nigeria has not been very successful because of the approach adopted by the government. The study recommended that subsequently, every bailout from the Nigerian government should be a product of an Act of Parliament, bailout schemes should have specific tools for measuring performance and be guided by specific lines, among others.
\end{abstract}

Keywords: State intervention, bailout, legislation, execution, package, economic stabilization

\section{Introduction}

The capitalist economic philosophy essentially advocates limited government involvement in business activities. It is a system in which private individuals/firms have full control of the means of production in the society. Basically, what should be produced, in what quantity, how it should be distributed and who should consume what is determined by the forces of demand and supply. It is commonly described as the "free market" system, meaning government has little or no role in its modus operandi, hence the popular saying "government has no business in business." In other words, the capitalist system has some inbuilt mechanisms that regulate its operations. As Bremmer (2010) puts it, (and also repeated in Bremmer, 2011) "free-market, capitalism is a game with referees who exist only to ensure proper enforcement of recognized rules and with players involved in genuine competition. Government's only role is to ensure that the rules are written effectively and fairly". All the states who are ardent supporters of the capitalist economic system are proud of these so-called in-built mechanisms or values of the system. However, over the years it has been observed that various governments, even in the core capitalist states such as United States of America, Canada, Mexico, Britain etc, have intervened to bailout private firms on the verge of imminent collapse during economic crisis. 
In Nigeria, with the deepening of the global economic crisis, federal government has embarked on various forms of intervention (bailout), supporting both private firms and component units' governments. The effects of the global economic crisis (also called global financial market crisis) were made manifest in year 2009, with the drop in the growth rate from 6.2 percent in 2007 to 5 percent in 2008. Essentially, the economic crisis in US and Europe led to low demand for industrial products, which resulted in sharp drop in the levels of production and consequently demand for industrial inputs/raw materials mainly from Africa, including crude oil from Nigeria.

According to Cobbinah and Okpalaobieri (2011) the effects of the crisis manifested in Africa in form of drop in prices of commodities, decrease in world trade, huge fall in receipts from overseas, and shortfall or interruption in the flows of investments, especially foreign direct investments. Thus, there was a huge decline in Nigeria's foreign exchange generation, slowdown of economic activities and the attendant sack of employees by firms and inability of government at the state and local government levels to pay staff for months, hence, the federal government's invention to salvage the situation. Thus, the main objective of this paper is to ascertain the extent to which government invention has helped stabilize the Nigerian economy, when compared with the experience of the United States. The paper would argue that the impact of state intervention in the US, in stabilizing the economy, was more palpable than the impact in Nigeria. The rest of the paper would be developed under the following headings: the concept of state intervention/bailout meaning of economic recession and stabilization, methodology, the US approach to state intervention, the Nigeria experience with state invention, lessons from the US and conclusion.

\section{The Concept of State Intervention/Bailout}

The desirability or otherwise of state intervention or bailout in a free-market economy has been a source of debate among modern and post-modern economists especially since the $2007-2008$ global financial crisis. While to some it is necessary to stabilize an economy in deep seated crises, others hold the view that the state of affected enterprises should be left to the forces of demand and supply or the market forces. The debate may go on for a much longer period without any definitive consensual position. The question is: what is a bailout? A bailout is a rescue arrangement made, especially a financial rescue, to safeguard an individual or group of individuals or a firm or group of firms. It is a term used to describe financial support or assistance given to a company or country facing serious financial difficulty or bankruptcy. In this regard, the purpose of such intervention is to bring the company back on its feet for further profitability and functionality in the economy. To Proprio (2017) bailout helps a distressed company to fail gracefully without spreading the harmful effects of its failure to the larger economy. In such circumstances, bailout is seen as a necessity in order to prevent greater socio-economic failures.

According to the online Etymology Dictionary, the term bailout has its origin from the Maritime sector where it involves the act of removing water from a sinking vessel using a smaller bucket to salvage the vessel. The practice of state intervention or bailout in economic sense was first made manifest in the US during the Great depression of the 1930s, when the Home Owners' Loan Corporation was created by the government to ameliorate suffering of house owners who had lost jobs and means of livelihood as a result of the depression (Davis, 2014). To Ludwig Von Mises, quoted in Nyquist (2013), "the idea underlying all interventionist policies is that the higher income and wealth of the more affluent part of the population is a fund which can be freely used for the improvement of the condition of the less prosperous". Hence, Nyquist wrote, "whether we are talking about Obama-care or tax increases, many policies are justified as an attempt to benefit the poor at the expense of the rich."

Still commenting on the desirability of the emergence-type state intervention/ bailout, Sachs (2008) described the bailout of the three US car markets (GM, Chrysler and Ford) as bitter pills that must be taken; however, he added that the assertion of poor management likely being responsible for the total failure of the car companies was not a sufficient reason and has the capacity of further distressing the already fragile economic environment of the US at the time, since up to three million jobs would have been lost if they had gone bankrupt. On the contrary, Hugh Hewitt, strongly rejected the bailout of the three big US car makers, describing it as an unacceptable buck passing 
to taxpayers. To him, the view that inept management at the car companies led to their failure follows that they should be disassembled naturally by the forces of demand and supply (i.e. free market forces). He believed that such dismantling would create opportunities for entrepreneurs to arise from the ashes, and that bailout such as was given to the three auto-giants is an indication of decline in the levels of business standards or qualities in the big companies, thus, arousing unguided risk taking, causing moral danger through the guarantee of the possibility of remedies that ought not to be.

Essentially, since the era of the Great Depression to date, different countries across the world have provided various forms of bailouts to firms at different times. The main reason for state bailout, according to Cobbinah and Okpalaobieri (2011) is to put a floor under a recession and pave the way for a return to growth. In other words, it is a move to prevent businesses from dying, with the "belief that the effects of the collapse would be much worse on the economy than to help liquidate the assets until the businesses can get back" to full operation (Economic Confidential, 2010). Some of the forms of bailout in practice are: tariff changes, tax and interest rate cuts, robust unemployment, education and health care benefits, fiscal stimulus packages, subsidies to sectors/firms, encouragement of local production, trade remedy measures, lessen liquidity constraints and promotion of consumer confidence. All these forms of state intervention are geared towards economic stabilization and recovery.

\section{Meaning of Economic Recession and Economic Stabilization}

The word recession means reduction and withdrawal of activities. It describes a period of reduced economic activity in a society. The National Bureau of Economic Research (NBER) defines a recession as "a significant decline in economic activity spread across the economy, lasting more than a few months, normally visible in a real gross domestic product (GDP), real income, employment, industrial production and wholesale - retail sales" (Morah, 2017). Statisticians usually define economic recession as a negative real GDP growth rate for two or more consecutive quarters (Amadeo, 2017). To Kroon (2007), GDP is the market value of all the goods and services produced within a country in a given period of time. According to Noko (2016), judging from this stand point, Nigeria is experiencing economic recession currently, since the first and second quarters growth in 2016 are -0.36 percent and -1.5 percent respectively. It is also described as a business cycle contraction which results in a general slowdown in economic activities. A number factors are responsible economic recession, namely high interest rate that discourage investors, mass layoffs and rising unemployment, which create slowdown in retail sales, high inflation and general rise in price of goods and services, which leads to low purchasing power and loss of business and consumer confidence on the economy, etc, (Noko, 2016).

To come out of recession concerted efforts must be made to first stabilize the economy and gradually achieve growth. So what is economic stability? The Ask.com website posits that economic stability is "a common term used to describe the financial system of a country that shows a consistently low rate of inflation and minor variations in the output growth". It added that, economic stability "is normally taken to be a required condition for any developed state, and the central bank is usually seen to encourage the process for this condition through various plans, policies and actions". Business Dictionary (2017) sees economic stability as the financial system of a nation that displays only minor fluctuation in output growth and shows a consistently low inflation rate. To Onwe (2014), it refers to an absence of excessive fluctuations in the macro-economy. As the Chegg study website puts it, an economy with fairly constant output growth and low and stable inflation would be considered to be economically stable.

The question is: why is economic stable important? Essentially, economic stable is crucial or weighty in a nation's life for a number of reasons. Some of these are: (i) avoidance of economic and financial crises; (ii) enhancement and encouragement of large swing in economic activity; (iii) avoidance or reduction of high inflation and excessive volatility in foreign exchange and financial markets, (iv) encouragement of large/huge investments, (v) promotion of certainty and economic growth, (vi) improvement in the standard of living, and (vii) reduction to the bearest minimum the volatility of the economy. Indeed, economic stability or stabilization is highly desirable in every 
country, be it developed or developing.

\section{Methodology}

The study adopted the documentary/library research method; therefore it was mainly qualitative in nature. This involves the use of secondary data (existing written works) drawn from textbooks, journal articles, information from newspapers, magazines and internet materials as well as facsimile. The works were selected based on their reliability and validity in relation to the topic under investigation. In addition, the secondary data were analyzed using the method of content analysis. To Hsieh and Shannon (2005) qualitative content analysis is a research method for the subjective interpretation of the content of text data through the systematic classification process of coding and identifying themes or patterns. While Babbie (2007) describes content analysis as the study of recorded human communications such as books, websites, paintings and laws. Thus, it is structured analysis that applied to documents rather than observations in non-verbal behaviour (Kalagbor, 2012). Content analysis is mainly inductive in application. It is concerned with drawing or establishing relationships between or among words, terms, concepts or phenomena being studied and analyzed. Therefore, the use of content analysis in this study was to show the relationships or differences in the bailout strategies/approaches adopted in Nigeria and United States of America as well as their impact in stabilizing the two economies. Essentially, content analysis was deemed to be the most appropriate technique for analyzing the secondary data in this study in view of the fact that it is simple, and could hardly be manipulated by the researchers because it is already documented and in relatively permanent state.

\section{The US Approach to State Intervention/Bailout}

The United States of America has a long history of government intervention in rescuing private sector businesses and individuals in order to stabilize its economy and to put the country on path of economic recovery and growth. According to Davis (2014), the October 2008 enactment of the Emergency Economic Stabilization Act (EESA), which made provision of $\$ 700$ billion to rescue the financial sector was one of the last in the lengthy records of past US government bailouts, which dates back to the period of the panic of 1792, when the federal government bailed out firms in the United States. Essentially, the EESA provided funds that save big mortgage insurers like Fannie Mac, Freddie Mac, and the American International Group (AIG) as well as a number of distressed banks in US. As Bremmer (2010) opined, the market meltdown of 2008 proved a turning point because it reversed a move towards less government intervention in the US. This bailout came at a period when the US and its European allies, through the Bretton Wood institutions (International Monetary Fund and World Bank) were insisting that developing nations move towards less government intervention/involvement in the development processes of their countries. As Ekekwe (2009) puts it "state intervention, hitherto much denied and glossed over under the hidden hand, became acceptable and respectable, as it had been under Keynesianism and during the great depression of the 1930s." In addition, upon assumption of office, President Obama drafted another stimulus package, tilted the American Recovery and Reinvestment bill, which was eventually passed into law by congress in February 2009 as the American Recovery and Reinvestment Act (ARRA). According to Amadeo (2017), the ARRA was aimed at ending the 2008 recession by spurring consumer spending and saving between 900.000 to 2.3 million jobs. She (Kimberly Amadeo), posits that the ARRA had three spending categories to include: (1) tax cuts by $\$ 288$ billion, (2) spending of $\$ 244$ billion in extended unemployment benefits, education and health care and (3) job creation allocation of $\$ 275$ billion in federal contracts, grants and loans.

Yet another bailout package was the auto industry loan. In the US the bailout was targeted at specific companies in the real sector, particularly General Motors, Chrysler and Ford, and this had huge impacted on the sector and economy in general. According to the Associated press the big three automakers in November 2008 asked for $\$ 50$ billion from congress to avoid bankruptcy and the loss of three million jobs. Congress approved the loan but tied it to the development of energy efficient vehicles. In this package the government also provided funds as incentives for new car 
buyers. Two of such incentives are government backing of all new car warranties and all new car buyers are allowed to deduct all car sales and excise taxes. Furthermore, Davis (2014) noted that, the government massively cut interest rate lower to encourage a favorable business environment, which theoretically will help the economy to stabilize. Also, the government spent huge resources on public goods - infrastructure, health care and education, etc. Such spending on public goods were visible and therefore impacted on the lives of the citizenry and helped to stabilize the economy.

By November, 2009, observers from different schools of thought assert that the state intervention, especially the Obama bailout, as unacceptable as it was, was working. For instance, Amadeo (2017) observed that, the stimulus Act was aimed at saving 900,000 to 2.3 million jobs; as at October 30 2009, it has saved 640,329 jobs. Amadeo (2016) disclosed that by June 2009, GM and Chrysler emerged from bankruptcy and with the help of the bailout created 340,000 additional jobs. This greatly impacted positively on the unemployment situation in the country. However, she added that, later in 2010 the recession made GM to downsize its employees and decreased production even though it received bailout. Amadeo asserts that, inspite of the challenges of the recession, by 2010 the US economy expanded by 2.5 percent. Most contributory factor being the extended unemployment benefits, for resources were made available to the unemployed that increased aggregate demand and consumption. Nonetheless, it is important to note that success was not only attributable to the stimulus/bailout packages, but the fact that there was the right mix of policies, especially monetary policy and fiscal policy.

\section{The Nigerian Experience with State Intervention}

Like the US and many other countries of the world, the Nigerian state/government has embarked on various types of intervention/bailout to salvage the nation's economy from recession. Successive regimes have intervened by providing funds to rescue distressed private enterprises. With the collapse of the stock market in 2008 and the imminent collapse of a number of banks, the Central Bank of Nigeria (CBN) intervened to stabilize these businesses. The CBN under Lamido Sanusi injected N400 billion naira into those ailing banks to help remove panic from the banking sector. If the banks rescued had been allowed to collapse all their staff across the country would have been thrown in to the labour market. Basically, the CBN's injection of funds into the distressed banks saved the workers and enhanced public confidence in the sector.

In addition, the government of President Goodluck Jonathan provided bailout funds to the aviation industry and the real sector. Each of the two sectors got N500 billion naira intervention fund to enable them remain in operation and boost their capacities. Also, the government made provision for the disbursement of N200 billion naira to be loaned to farmers under the Commercial Agricultural Credit Scheme, N361.2 billion naira for investment in critical infrastructure, injection of N100 billion naira multilateral loan in critical sectors of the economy and the lower tariffs regime under the 2008 - 2012 Nigerian Customs and Tariff Book to encourage the importation of raw materials to stimulate local Industrial Production and manufacturing activities (Cobbinah and Okpalaobieri, 2013). Cobbinah and Okpalaobieri (2013) observed that most of the intervention funds were spent on the financial and energy sectors. They asserted that between 2009 and 2012 a total of $\$ 5.2$ billion dollars was spent on these sectors. Inspite of all these interventions the country slipped into recession in 2016.

Similarly, since assumption of office President Muhammadu Buhari administration has provided various forms of bailouts, including the sharing of $\$ 2.1$ billion dollar in fresh allocation from NLNG between the federal and the state governments, special intervention funds from the CBN of between N250 to N300 billion naira to states to enable them pay backlog of salaries at very low interest, payment of $\mathrm{N} 5,000.00$ naira stipends to selected vulnerable people and the N-Power employment scheme. Yet, Ogunfunwa (2016) has noted with dismay that experts predict more job losses in the days ahead as the economy wobbles. The National Bureau of Statistics (NBS) data in March 2017 revealed that 3 million jobs were lost in one year - February 2016 to February 2017. It is important to note that, even with all the bailouts given to the different sectors the impact is minimal. There was massive loss of jobs in the banks, aviation and the real sector. 
Also, many who are in employment are either underemployed, salaries slashed or owed several month's salary arrears. It is also noteworthy that all the stimulus and intervention packages in Nigeria are not products of legislations (that is, not through Acts of Parliament), rather they are products of "executive fiat", using the "rule of the thumb" and felt need approach. In February 2017, in an effort to put the economy on the path of recovery the Federal government launched the Economic Recovery and Growth Plan. The plan was presented during the Second Presidential Business Forum presided over by Prof. Osinbajo, at the Presidential Villa in Abuja. At the launch, experts advised the government on how to address the current economic challenges, restore growth and reposition the economic for sustainable development.

One of such advice came from Prof. Akpan Ekpo, who urged the government to identify expenditures on capital projects with a view to reversing the economic challenges. He added that the plan should articulate policies and strategies that would deal with the structural problems of the economy such as power, roads, railway, etc (Aderinokun, 2017). Also, experts asserted the need for public policies in Nigeria, including the ERGP, to have measurable, deliverables within specific timelines so as to increase public sector productivity. According to Aderinokun (2017), the analysts from Eczellon Capital asserting the need for setting measureable outcomes of public institutions at the Presidential Business Forum insisted that government must adhere to the SMART (Specific, Measureable, Achievable, Relevant and Time-bound) concept in its undertakings especially in the area of policy formulation and implementation. In their words:

"irrespective of the content of the plan we reiterate the need for it to be SMART.... Anything short of this may render the ERGP to be another bogus document that may have little or no impact on the economy like previous economic development plans."

\section{State Intervention: Some Lessons from the US}

As earlier stated, different countries across the globe have embarked on various kinds of intervention/bailouts to help stabilize their economics, including United States of America and Nigeria. However, the approach to the granting of bailout by these two nations differ, hence the outcomes of the bailouts also differ. When compared to Nigeria, the US has been more successful in using bailout funds to stabilize its economy and subsequently moved out of recession. The question is: How is the US approach to state intervention/bailout different from that which obtained in Nigeria? Put differently, what are the lessons the Nigerian state should learn from the US with respect to its approach to bailout? A few of these differences are discussed below.

First, in the US every state intervention/bailout was based on legislation or an Act of Parliament. This is not the case in Nigeria, bailout were not through Act of parliament, but rather through "executive fiat" or rule of the thumb. For instance, in the US we have such bailout legislation as the Emergency Economic Stabilization Act of 2008 (Nolen, 2008), the American Recovery and Reinvestment Act of 2009 (Bromann, 2012), etc, all of which specified the amount involved, how such money and resources should be used and what are the specific expected outcomes with time lines. On the contrary, in Nigeria, bailouts are not predicated on legislations to give them the legal teeth needed for their effective and efficient operationalization, hence the difficulty in measuring the performance of bailout in the country.

Second, in the US, bailouts were targeted at the real sector to encourage production. As Davis (2014) observed, the US Congress through the Financial Institutions Reform, Recovery and Enforcement Act of 1989, injected the sum of $\$ 293.3$ billion into the struggling industries. Similarly, the ARRA of 2009 provided funds for the big three auto giants in the US: General Motors, Chrysler and Ford. On the other hand, in Nigeria, the bulk of the bailouts were used to fund consumption, such as bailout to state governments to pay salaries which were used to purchase goods manufactured abroad. This did not really improve the economy because most of what we consume in Nigeria are imported and not locally produced.

Third, in the US, bailouts were given loans provided for consumers to increase aggregate demand. As the firms bailed out produce, the consumers have funds at hand to buy so as to stimulate the economy and put it on the path of growth and recovery. A good example is the 
extensive unemployment benefits provided in the ARRA of 2009. The ARRA of 2009 also provided grants and loans to individuals, to the sum of $\$ 275$ billion dollar, to enable them create jobs. In Nigeria, while it is true that government made provision for loans to individuals to create jobs and gave stipends (N5,000.00 naira monthly stipends to vulnerable groups), the sincerity was questionable and the outcome of these efforts is opaque.

Lastly, in the US, as part of the bailouts to enhance economic stabilization and recovery there were tax and interest rate cuts. As Davis (2014) posited, various federal taxes and key interest rate were cut very low to encourage a favorable business environment in order to help the economy. Similarly, Amadeo (2017) disclosed that part of the economic stimulus package for the big automakers was the provision allowing new car buyers to deduct all car sales and excise taxes. This was not the case in Nigeria; rather interest rate was left high, at double digit. Though, the Monetary Policy Committee (MPC) pegged the interest rate at 14 and 22 percent, most often loans are given at 25 percent interest rate. Even the government borrow at 17 percent, thus most of the credits are made available to the government and to private businesses for investment purposes. In Nigeria, there is also an obvious case of policy disharmony between fiscal policy and monetary policy. For instance, the fiscal policy authorities are focusing on encouraging investments from private individuals and businesses to create jobs, increase access to income and equitably redistribute wealth in the country. On the other hand, those managing the monetary policy maintain high interest rate thereby making borrowing very difficult. High interest rates discourage investment and therefore economic growth.

\section{Conclusion}

From the foregoing, it is clear that in theory the capitalist system/state negate government involvement in business activities; however, as has been demonstrated above, most adherents of capitalism violate the principle and philosophy of government has "no business in business". During economic and financial crisis states intervene by granting bailouts to businesses to stabilize their economies and accelerate recovery. Focusing on US and Nigeria reveal that, the two nations have granted bailout to different sectors of their economies. Nonetheless, state interventions or bailouts produced better outcomes in the US than Nigeria. This is largely because of the approaches adopted in the two countries. While in the US every bailout is a product of legislation and wellguided in its administration/execution, in Nigeria bailouts are products of "executive fiat", thus suffer poor execution. Thus, the conclusion of this paper is that state intervention/bailout in Nigeria has not been very successful because of the approach adopted by the Nigerian government. This is seen in the way and manner the N200 billion naira Agricultural Credit Scheme was managed, among other such schemes.

\section{Recommendation}

In the light of the findings of this study, the following recommendations are made:

(a) Subsequently, every bailout from the Nigerian government should be a product of an Act of Parliament. This would enable the lawmakers to articulate all the major determinants for the approval of the bailout and also clearly state what it is to achieve with specific timelines.

(b) Public policies and programmes, including those related to bailouts should have specific tools for measuring performance and be guided by specific time line or should time-bound.

(c) To stabilize the economy and move towards recovery and growth, government should harmonize the fiscal and monetary policies in the country. This, no doubt, will bring down interest rate, make available capital for investment, create jobs and grow the economy.

\section{References}

Aderinokun, K. (2017), Formulating Nigeria's Economic Recovery Plan, This Day Newspaper, Online February 19, 2017. 
Amadeo, K. (2017), What was Obama's Stimulus Package? Hosted Online at www.thebalacne.com/what-wasobama's-stimulus-package-3305625

Amadeo, K. (2017). What is a Recession? Examples, Impact, Benefits hosted online at www.the-balance.com/what-is-a-recession?

Ask.com, What is Economic Stability? Hosted online at www.reference.com/world-veiw/economicstability231625acffa1b46f.

Babbie, E. (2007), The Practice of Social Research, Wadsworth: Cengage Learning.

Bremmer, I. (2010), The End of the Free Market: Who wins the War between States and Corporations? New York: Penguin Group.

Bremmer, I. (2011), The End of the Free Market: Why America Must Defend the Free Market Economy, hosted online at www.huffpost.com/us/entry/576214.

Bromann, K. (2012), The American Recovery and Reinvestment Act of 2009: An Investigation into the Determinants of Funds Awarded to States. Hosted online at www.martin.uky.edu

Business Dictionary (2017) hosted online at www.businessdictionary.com .

Cobbinah, P. and Okpalaobieri, D. (2011), State Bailouts in an Era of Financial Crisis: Lessons from Africa, A Publication of the Global Trade Alert. Pp2-12

Davis, M. (2014) Top 6 U.S. Government Financial Bailouts. Hosted online at www.investopeida.com/articles/economic/government-financial-bailout-asp.

Economic Confidential (2010), The Effects of Sanusi's Bailout Funds, hosted online at https/economicconfidential.com/financial/theeffects-of-sanusis-bailout-funds/

Ekekwe, E.N. (2009), The 2007 - 2008 Crash and International Political Economy, Port Harcourt: Amajor and Coy. Nig. Pp30-38.

Hsieth, H.F. and Shannon, S.E. (2005), Three Approaches to Analysis. Qualitative Health Research, Vol 15 No.9, Pp $1277-1288$.

Kalagbor, S.B. (2012) The Supreme Court and Political Development in Nigeria (1979 - 2010), A Ph.D Dissertation submitted to the School of Graduate Studies, University of Port Harcourt (unpublished).

Kroon, G.E. (2007), Macro-economic the Easy Way, an eBook, hosted online at http://books.google.com.ng

Morah, C. (2017), What Causes a Recession? hosted online at www.investopedia.com/ask/answers/08/causesof-recession.asp.

Noko, E. (2016), Economic Recession in Nigeria: Causes and Solution, hosted online at sept10educachinfo 2016.

Nolen, J.L. (2008), Emergency Economic Stabilization Act of 2008 (ESSA): United States Legislation, hosted online at www.birtannia.com

Nyquist, J.R. (2013), Economic Recovery Vs. Government Intervention, hosted online at www.financialsense.com/contributor/j-r-nyquist June 10, 2013 p.1

Odu, O. (2017), The Real Effect and Meaning of the Bailout Fund - Governors, Nigerian Monitor Newspaper Online, March 11, 2017.

Ogunfunwa, I. (2016), Experts Predict More Job Losses as Economy Wobbles, Punch Newspaper Online 3 October, 2016.

Onwe, B.U (2014), Implication of Deficit Financing on Economic Growth in Nigeria, in European Journal of Accountings, Auditing and Financial Research, Vol. 2. No 10, Pp. 122- 135 (wwweajournals.org )

Proprio, M. (2017), USD Crash Might Happen in October 2017! Is Investing in Crypto the Safest Way to Go? hosted online at www.steemit.com/.../usd-crash-might-happen-in-oct-2017-is-investing-in-crypto-thesafest-way-to-go?

Sachs, J.D. (2008), A Bridge for the Carmakers, Washingtonpost.com. 